\title{
PAGIMDŽIUSIŲ MOTERŲ DALYVAVIMĄ MOTINOS PIENO DONORYSTËJE LEMIANTYS VEIKSNIAI
}

\author{
Alina Vaškelyte் $\dot{1}^{1,2}$, Judita Aniulyte் $\dot{\mathrm{e}}^{1}$ \\ ${ }^{1}$ Lietuvos sveikatos mokslu universiteto Slaugos fakultetas, Slaugos ir rüpybos katedra, \\ ${ }^{2}$ Kauno kolegijos Medicinos fakultetas, Slaugos katedra
}

Raktažodžiai: pagimdžiusios moterys, pieno donoryste, pieno bankas, dalyvavimą lemiantys veiksniai.

\begin{abstract}
Santrauka
Esant situacijų, kuomet naujagimis negali gauti savo motinos pieno, kaip pirmoji alternatyva rekomenduojamas donorinis motinos pienas. Kaip vienas pagrindinių pieno bankų iššūkių yra ịvardijamas pieno aukojimo masto didinimas, o tam itin svarbu sutelkti naujų donorių, didinti kiekvienos moters aukojamo pieno kiekị ir dažnį. Šiam tikslui pasiekti svarbu nustatyti su dalyvavimu pieno donorysteje susijusias problemas, tam įtakos turinčius veiksnius ir iggyvendinti tam tikrus strateginius veiksmus, galinčius prisidèti prie pieno donorystès skatinimo.

Siekiant išanalizuoti pagimdžiusių moterų dalyvavimą motinos pieno donorysteje lemiančius veiksnius, buvo atliktas tyrimas vienoje iš Lietuvos ligoninių Akušerijos ir ginekologijos klinikoje bei Neonatologijos klinikoje. Tyrime dalyvavo 257 šioje ligoninèje pagimdžiusios moterys, kurių naujagimiai buvo prižiūrimi akušerijos, naujagimių ligų ar naujagimių intensyviosios terapijos skyriuose. Atliekant tyrimą buvo taikoma anketinè apklausa, naudojant autoriu sudarytą anoniminę anketą.

Tyrimo rezultatai atskleide, kad didžioji dalis pagimdžiusių moterų sutiktų tapti pieno banko donoremis ir vartoti pieną iš pieno banko savo naujagimiui. Paaukoti savo pieno donorinio motinos pieno bankui pagimdžiusios moterys dažniausiai sutiktų dèl noro padèti kitoms mamoms ir naujagimiams, kuriems to reikia, o nesutiktų dèl baimès, kad gali neužtekti pieno savo naujagimiui. Vartoti donorini motinos pieną iš pieno banko moterys dažniausiai sutiktų, nes motinos pienas yra geriausias maisto šaltinis naujagimiui, o atsisakymą dažniausiai lemtų pirmenybès teikimas kitokiam maitinimo būdui.
\end{abstract}

\section{Ivadas}

Motinos pienas - optimaliausias maisto šaltinis naujagimiui [1]. Didžiosios pasaulio sveikatos priežiūros organizacijos, tokios kaip Pasaulio sveikatos organizacija (PSO), Amerikos pediatru akademija (APA), skatina bei remia motinos pieno vartojimą, maitinimą krūtimi [2]. Yra žinoma, kad žindymas turi trumpalaikès ir ilgalaikès naudos tiek naujagimio ir kūdikio [3-4], tiek motinos sveikatai [5], kuri dideja priklausomai nuo žindymo trukmès.

Nepaisant motinos pieno bei žindymo privalumų, pasitaiko situacijų, kuomet naujagimis negali gauti jam tinkamiausio maisto - savo motinos pieno - arba jo kiekio neužtenka. Dažniausiai su šia problema susiduria neišnešiotų naujagimių motinos, kurių pieno gamybą apsunkina fizinès ir emocinès negandos: pačios moters liga, patiriamas stresas, atskirtis nuo savo naujagimio [6-7]. Esant tokioms situacijoms, kuomet naujagimis negali gauti savo motinos pieno, kaip pirmają alternatyvą PSO, APA, Jungtinių Tautų vaikų fondas (angl. UNICEF) rekomenduoja donorini motinos pieną [8-10] - pieną iš krūties moters, kuri nèra ši pieną gaunančio naujagimio motina [11].

Užtikrinti savo motinų pieno negaunančių naujagimių mitybos poreikius padeda donorinio motinos pieno bankai - juose yra surenkamas, ištiriamas, paruošiamas ir paskirstomas paaukotas pienas iš krūties. Pieno banko donoremis gali tapti sveikos moterys, auginančios kūdikius iki šešių mènesių amžiaus ir turinčios atliekamo pieno. Tam, kad naujagimius pasiekiantis donorinis pienas būtų saugus, jis yra atitinkamai ištiriamas ir paruošiamas - toks apdorojimas padeda efektyviai apsaugoti pieną nuo galimo užteršimo virusais ar bakterijomis [12].

Nors Europoje yra daugiau nei 200 donorinio motinos pieno bankų, aprūpinančių naujagimius paaukotu pienu iš krūties [13], tačiau surenkamo pieno kiekis nèra pakankamas pamaitinti visų naujagimių, kuriems tai yra gyvybiškai svarbu [14]. Todèl vis dažniau prioritetinèmis veiklos kryptimis pieno bankuose tampa naujų donorių sutelkimas, 
kiekvienos moters aukojimo masto didinimas. Šiam tikslui pasiekti labai svarbu nustatyti su dalyvavimu pieno donorystèje susijusias problemas, tam ịtakos turinčius veiksnius ir igyvendinti tam tikrus strateginius veiksmus, galinčius prisidèti prie pieno donorystès skatinimo. Sveikatos priežiūros specialistų vaidmuo šioje srityje yra itin svarbus, kadangi dauguma moterų nori būti jų informuotos, padrąsintos dalyvauti pieno donorysteje [14-15].

Lietuvoje pirmasis donorinio motinos pieno bankas buvo atidarytas $2016 \mathrm{~m}$. gruodžio $1 \mathrm{~d}$. [12], todèl iki šiol šalyje nėra daug atliktų tyrimų, susijusių su motinos pieno donorystès tema. Nustačius, kokie veiksniai turi ịtakos dalyvavimui šioje veikloje, būtu galima padèti nuspręsti, ar reikia imtis priemonių (jei reikia - kokių) pagerinti pieno donorystès situaciją.

Tikslas - išanalizuoti pagimdžiusių moterų dalyvavimą motinos pieno donorystėje lemiančius veiksnius.

\section{Tyrimo medžiaga ir metodai}

Tyrimas buvo vykdomas 2017 - $2018 \mathrm{~m}$. vienoje iš Lietuvos ligoninių Akušerijos ir ginekologijos klinikoje -

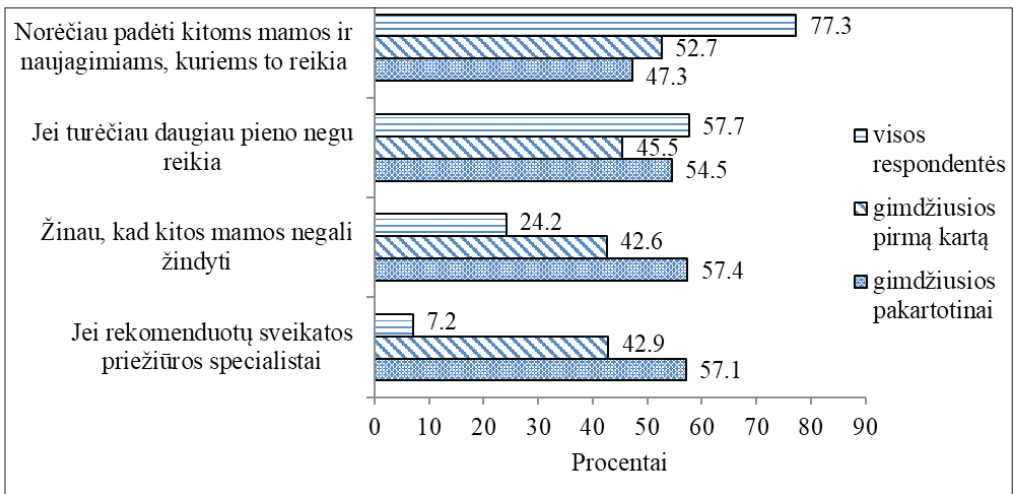

1 pav. Priežastys, dèl kurių respondentès sutiktų paaukoti savo pieno donorinio motinos pieno bankui

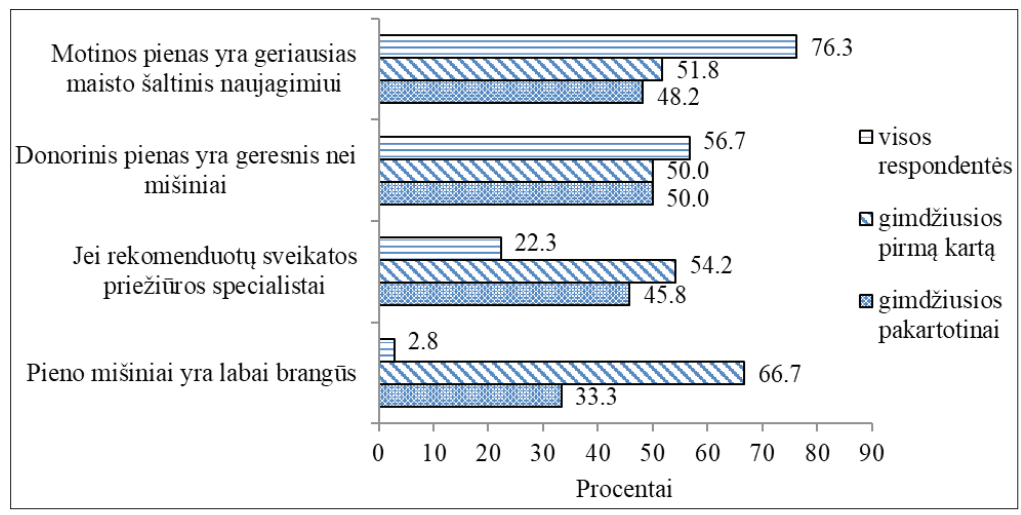

2 pav. Priežastys, dèl kurių respondentès sutiktų vartoti donorinị motinos pieną iš pieno banko akušerijos skyriuje bei Neonatologijos klinikoje - naujagimių ligų ir naujagimių intensyviosios terapijos skyriuose. Dalyvauti tyrime buvo kviečiamos tiriamuoju laikotarpiu šioje ligoninèje pagimdžiusios moterys, kurių naujagimiai buvo prižiūrimi minètuose skyriuose. Buvo taikoma anketinè apklausa, naudojant autorių sudarytą anoniminę anketą, parengtą remiantis moksline literatūra.

Dalyvauti tyrime buvo pakviestos 265 pagimdžiusios moterys, iš kurių aštuonios nesutiko dalyvauti. Buvo išdalintos 257 anketos, iš jų sugrižo 247, tinkamos analizuoti buvo 243 anketos. Atsako dažnis - 96,1 proc.

Tyrimo dalyvès pagal amžių buvo suskirstytos ị keturias grupes: 22,6 proc. $(n=55)$ respondenčių buvo 25 metų ir jaunesnès, daugiau nei trečdalis - 36,6 proc. $(\mathrm{n}=89) 26-30$ metų amžiaus, 26,3 proc. (n=64) 31 - 35 metų amžiaus, mažiausia dalis $-14,4$ proc. $(n=35)$ buvo 36 metų ir vyresnès.

Pagal šeiminę padètị pagimdžiusios moterys pasiskirstė taip: 0,8 proc. $(n=2)$ buvo vienišos, 21,8 proc. $(n=53)$ gyveno su partneriu nesusituokusios. Didžioji dalis $-76,1$ proc. $(\mathrm{n}=185)$ buvo ištekejjusios, o 1,2 proc. $(\mathrm{n}=3)$ - išsiskyrusios.

Iš 243 respondenčių 7,4 proc. $(n=18)$ turèjo pagrindinị išsilavinimą, 18,5 proc. $(\mathrm{n}=45)$ - vidurini, 12,8 proc. $(\mathrm{n}=31)$ - profesinị. Daugiau nei pusè tiriamuju - 61,3 proc. $(n=149)$ buvo ịgijusios aukštaji išsilavinimą.

Pagal gyvenamają vietą tyrimo dalyvès pasiskirste taip: didžioji dalis $-79,8$ proc. $(\mathrm{n}=194)$ gyveno mieste, 7,0 proc. $(\mathrm{n}=17)-$ miestelyje, o 13,2 proc. $(\mathrm{n}=32)$ - kaime.

Iš visų tyrimo dalyvių apie pusè $-51,0$ proc. $(\mathrm{n}=124)$ gimdè pirmą kartą. Taip pat beveik pusè $-49,0$ proc. $(n=119)$ gimdè pakartotinai.

Pagal skyrių, kuriame buvo prižiūrimas jų naujagimis, respondentės pasiskirste taip: daugiau nei puse $-62,6$ proc. ( $\mathrm{n}=152)$ akušerijos skyriuje, 26,3 proc. $(\mathrm{n}=64)$ naujagimių ligų skyriuje, o 11,1 proc. $(\mathrm{n}=27)$ naujagimių intensyviosios terapijos skyriuje.

Gauti tyrimo rezultatai buvo palyginti tarp dviejų respondenčių grupių: gimdžiusių pirmą kartą $(\mathrm{n}=124)$ ir gimdžiusių pakartotinai $(\mathrm{n}=119)$.

Analizuojant tyrimo duomenis, nagrinèjamų požymių pasiskirstymas imtyje buvo aprašomas imties skaitinemis charakteristikomis - dažniu (n) ir procentiniu dažniu (proc.). Dviejų kokybinių požymių skirstinių palyginimui ir statistinès priklausomybès ịvertinimui taikytas chi kvadrato $\left(\chi^{2}\right)$ testas. Buvo 
pasirinktas 0,95 pasikliovimo lygmuo, 0,05 reikšmingumo lygmuo.

Tyrimui atlikti buvo gautas LSMU Bioetikos centro pritarimas Nr. BEC-AK(B)-36.

\section{Rezultatai}

Didžioji dalis tyrimo dalyvių ( 79,8 proc., $\mathrm{n}=194)$ sutiktų tapti pieno banko donoremis. Iš jų didžioji dalis $(77,3$ proc., $\mathrm{n}=150$ ) savo pieno paaukotų, nes norètų padèti kitoms mamoms ir naujagimiams, kuriems to reikia. Daugiau nei pusė $(57,7$ proc., $n=112)$ respondenčių paaukotų pieno, jei jo turètų daugiau negu reikia, 24,2 proc. $(n=47)$ - nes žino, kad kitos mamos negali žindyti, 7,2 proc. $(n=14)$ - jei tai rekomenduotų sveikatos priežiūros specialistai. Šiuo klausimu tarp pirmą kartą ir pakartotinai gimdžiusių tiriamujjų

1 lentelè. Priežastys, dèl kurių respondentès nesutiktų paaukoti savo pieno donorinio motinos pieno bankui.

\begin{tabular}{|l|l|l|l|}
\hline Priežastys & $\begin{array}{l}\text { Visos res- } \\
\text { pondentès, } \\
\text { proc. (n) }\end{array}$ & $\begin{array}{l}\text { Gimdžiusios } \\
\text { pirmą kartą, } \\
\text { proc. (n) }\end{array}$ & $\begin{array}{l}\text { Gimdžiusios } \\
\text { pakartotinai, } \\
\text { proc. (n) }\end{array}$ \\
\hline $\begin{array}{l}\text { Bijotų, kad gali neužtekti pieno } \\
\text { savo naujagimiui }\end{array}$ & $73,5(36)$ & $44,4(16)$ & $55,6(20)$ \\
\hline $\begin{array}{l}\text { Neturi apie tai pakankamai infor- } \\
\text { macijos }\end{array}$ & $28,6(14)$ & $57,1(8)$ & $42,9(6)$ \\
\hline Neturètų tam laiko & $24,5(12)$ & $33,3(4)$ & $66,7(8)$ \\
\hline $\begin{array}{l}\text { Tai gali nepatikti jų šeimai ar an- } \\
\text { trajai pusei }\end{array}$ & $6,1(3)$ & $66,7(2)$ & $33,3(1)$ \\
\hline $\begin{array}{l}\text { Bijotų, kad dėl to gali nukarti } \\
\text { krūtys }\end{array}$ & $4,1(2)$ & $100,0(2)$ & $0,0(0)$ \\
\hline Nepatinka idèja & $4,1(2)$ & $0,0(2)$ & $100,0(0)$ \\
\hline
\end{tabular}

2 lentelè. Priežastys, dèl kurių respondentès nesutiktų vartoti donorinio motinos pieno iš pieno banko

\begin{tabular}{|l|c|c|c|}
\hline Priežastys & $\begin{array}{c}\text { Visos res- } \\
\text { pondentės, } \\
\text { proc. (n) }\end{array}$ & $\begin{array}{c}\text { Gimdžiusios } \\
\text { pirmą kartą, } \\
\text { proc. (n) }\end{array}$ & $\begin{array}{c}\text { Gimdžiusios } \\
\text { pakartotinai, } \\
\text { proc. (n) }\end{array}$ \\
\hline $\begin{array}{l}\text { Teiktụ pirmenybę kitokiam maiti- } \\
\text { nimo būdui }\end{array}$ & $57,1(16)$ & $43,8(7)$ & $56,3(9)$ \\
\hline $\begin{array}{l}\text { Bijotu infekcijų/ ligų perdavimo } \\
\text { naujagimiui rizikos }\end{array}$ & $50,0(14)$ & $50,0(7)$ & $50,0(7)$ \\
\hline $\begin{array}{l}\text { Donorinis pienas nepakankamai } \\
\text { higieniškas }\end{array}$ & $39,3(11)$ & $45,5(5)$ & $54,5(6)$ \\
\hline $\begin{array}{l}\text { Neturi apie tai pakankamai infor- } \\
\text { macijos }\end{array}$ & $35,7(10)$ & $20,0(2)$ & $80,0(8)$ \\
\hline Nepatinka ideja & $14,3(4)$ & $0,0(0)$ & $100,0(4)$ \\
\hline $\begin{array}{l}\text { Tai gali nepatikti jų šeimai ar an- } \\
\text { trajai pusei }\end{array}$ & $7,1(2)$ & $0,0(0)$ & $100,0(2)$ \\
\hline
\end{tabular}

reikšmingo skirtumo nebuvo (1 pav.).

Sutikimas paaukoti savo pieno donorinio motinos pieno bankui priklausè nuo to, kuriame skyriuje buvo prižiūrimas naujagimis: savo pieno paaukoti sutiktu 92,6 proc. $(n=25)$ naujagimių intensyviosios terapijos skyriuje, 87,5 proc. $(\mathrm{n}=56)$ naujagimių ligų skyriuje, 74,3 proc. $(\mathrm{n}=113)$ akušerijos skyriuje prižiūretų naujagimių mamų $(\mathrm{p}<0,05)$.

Iš respondenčių, kurios nesutiktų paaukoti savo pieno donorinio motinos pieno bankui (20,2 proc., $n=49)$, didžioji dalis $(73,5$ proc., $n=36)$ bijotų, kad gali neužtekti pieno savo naujagimiui. 28,6 proc. $(n=14)$ atsisakytų šios veiklos, kadangi neturi apie tai pakankamai informacijos, 24,5 proc. $(\mathrm{n}=12)$ - neturètų tam laiko. 6,1 proc. $(\mathrm{n}=3)$ manè, kad tai gali nepatikti jų šeimai ar antrajai pusei, 4,1 proc. $(n=2)-$ bijotų, kad dèl to gali nukarti krūtys. Dar 4,1 proc. $(n=2)$ tiriamujų netaptų pieno banko donoremis, nes nepatinka ši idèja. Šiuo klausimu tarp pirmą kartą ir pakartotinai gimdžiusių tiriamujų reikšmingo skirtumo nebuvo (1 lentelè).

Vartoti donorinį motinos pieną iš pieno banko, jei jo reikètų jų naujagimiui, sutiktų didžioji dalis $(88,5$ proc., $n=215)$ tyrimo dalyvių. Iš jų didžioji dalis $(76,3$ proc., $n=164)$ tai darytų, nes motinos pienas yra geriausias maisto šaltinis naujagimiui. Daugiau nei pusès $(56,7$ proc., $n=122)$ respondenčiu manymu, donorinis pienas yra geresnis nei mišiniai. Vartoti pieną iš pieno banko, jei tai rekomenduotų sveikatos priežiūros specialistai, sutiktų 22,3 proc. $(\mathrm{n}=48)$ tyrimo dalyvių. Dar 2,8 proc. $(\mathrm{n}=6)$ respondenčių tai darytų, nes mano, kad pieno mišiniai yra labai brangūs. Šiuo klausimu tarp pirmą kartą ir pakartotinai gimdžiusių tiriamujjų reikšmingo skirtumo nebuvo (2 pav.).

Sutikimas vartoti donorinį motinos pieną iš pieno banko priklause nuo to, kuriame skyriuje buvo prižiūrimas naujagimis: vartoti donorinį motinos pieną sutiktų 100,0 proc. $(\mathrm{n}=27)$ naujagimiu intensyviosios terapijos skyriuje, 95,3 proc. $(\mathrm{n}=61)$ naujagimių ligų skyriuje, 83,6 proc. $(\mathrm{n}=127)$ akušerijos skyriuje prižiūrètų naujagimių mamų $(\mathrm{p}<0,05)$.

Iš tiriamųjų, kurios nesutiktų vartoti donorinio motinos pieno iš pieno banko (11,5 proc., $\mathrm{n}=28)$, daugiau nei pusè $(57,1$ proc., $\mathrm{n}=16$ ) teiktų pirmenybę kitokiam maitinimo būdui. Pusè (50,0 proc., $\mathrm{n}=14)$ jų bijotų infekcijų/ ligų perdavimo nauja- 
gimiui rizikos. 39,3 proc. $(\mathrm{n}=11)$ tyrimo dalyvių atsisakytu maitinti savo naujagimi pienu iš pieno banko, nes mano, kad donorinis pienas nepakankamai higieniškas, 35,7 proc. $(\mathrm{n}=10)$ - neturi apie tai pakankamai informacijos. 14,3 proc. $(n=4)$ respondenčių nesutiktų vartoti pieno iš pieno banko, nes joms nepatinka ši idejja, o 7,1 proc. $(\mathrm{n}=2)$ mano, kad tai gali nepatikti jų šeimai ar antrajai pusei (2 lentelè).

Priežastys, dèl kurių respondentès nesutiktų vartoti donorinio motinos pieno iš pieno banko, tarp pirmą kartą ir pakartotinai gimdžiusių reikšmingai nesiskyrè (2 lentelè).

\section{Diskusija}

Tyrimo rezultatai parode, kad beveik 80 proc. pagimdžiusių moterų paaukotų savo pieno donorinio motinos pieno bankui. Turkijoje $(2009,2014)$ vykdytų tyrimų duomenimis, daugiau nei 60 proc. moterų pasiryžtų tokiu būdu dalyvauti pieno donorysteje $[11,16]$. Tuo tarpu pagal Italijoje (2014) atlikto tyrimo rezultatus, kiek mažiau nei pusė pagimdžiusių moterų norètų tapti pieno banko donoremis [14]. Taip pat mažiau nei pusé Nigerijoje (2014) vykdyto tyrimo dalyvių sutiktų paaukoti savo pieno tokiai ịstaigai [10].

Buvo nustatyta, kad dažniausiai pagimdžiusios moterys pasiryžtu tapti pieno banko donore, nes norètų padèti kitoms mamoms ir naujagimiams, kuriems to reikia. Tokia pat priežastis dažniausiai lèmė ir jau minètų Nigerijoje [10] ir Italijoje [14] vykdytų tyrimų dalyvių sutikimą paaukoti savo pieno. Tuo tarpu nenorą tapti pieno banko donoremis išreiškusios mūsų atlikto tyrimo dalyvès kaip pagrindinị tokio atsisakymo motyvą nurode baimę, kad gali neužtekti pieno savo naujagimiui, o mažiausia dalis atsisakiusiųjų teigè, kad joms nepatinka pati idèja. Kiek kitokia situacija matoma žvelgiant ị Nigerijoje vykdyto tyrimo rezultatus nepatinkanti idẻja buvo dažniausia tokio moterų pasirinkimo priežastis, o baimè neturèti pakankamai pieno savo naujagimiui - antra pagal dažnumą tarp šio tyrimo dalyvių [10].

Mūsų atlikto tyrimo duomenimis, vartoti donorinị motinos pieną iš pieno banko, jei to reikètų jų naujagimiui, sutiktų didžioji dalis - beveik 90 proc. pagimdžiusių moterų. Tuo tarpu abiejuose anksčiau minètuose Turkijoje vykdytuose tyrimuose tokių moterų dalis sudare apie pusę $[11,16]$, o Italijoje atliktame tyrime - kiek daugiau nei pusę visų respondenčių [14]. Tačiau pagal Nigerijoje vykdyto tyrimo duomenis, ten vartoti donorini pieną iš pieno banko sutiktų dar mažiau - tik kiek daugiau nei dešimtadalis pagimdžiusių moterų [10].

Dažniausia sutikimo vartoti donorinį motinos pieną priežastimi tiek tarp mūsų, tiek tarp Italijoje [14] ir Nigerijoje [10] atliktų tyrimų dalyvių buvo manymas, kad motinos pienas yra geriausias maisto šaltinis naujagimiui. Tuo tarpu nesutinkančios maitinti savo naujagimių donoriniu pienu iš pieno banko jau minètų Nigerijoje [10] ir Turkijoje [16] vykdyto tyrimo dalyvès dažniausiai baiminosi infekcijų, ligų perdavimo naujagimiui rizikos. Tokia pat atsisakymo priežastis tarp mūsų atlikto tyrimo dalyvių buvo antra pagal dažnumą, kadangi dažniausiai pagimdžiusios moterys nenaudotų pieno iš pieno banko, nes teiktų pirmenybę kitokiam maitinimo būdui.

\section{Išvados}

Didžioji dalis tyrimo dalyvių sutiktų tapti pieno banko donoremis ir vartoti pieną iš pieno banko savo naujagimiui.

Paaukoti savo pieno donorinio motinos pieno bankui pagimdžiusios moterys dažniausiai sutiktų dèl noro padèti kitoms mamoms ir naujagimiams, kuriems to reikia, o nesutiktų dèl baimès, kad gali neužtekti pieno savo naujagimiui.

Vartoti donorinị motinos pieną iš pieno banko moterys dažniausiai sutiktų dèl to, kad motinos pienas yra geriausias maisto šaltinis naujagimiui, o atsisakymą dažniausiai lemtų pirmenybès teikimas kitokiam maitinimo būdui.

\section{Literatūra}

1. Bertino E, Di Nicola P, Giuliani F, Peila C, Cester E, Vassia C. et al. Benefits of human milk in preterm infant feeding. J Pediatr Neonat Individual Med 2012; 1(1):19-24.

2. Updegrove K. Nonprofit human milk banking in the United States. J Midwifery Womens Health 2013; 58(5):502-508. https://doi.org/10.1111/j.1542-2011.2012.00267.x

3. Mosca F, Gianni ML. Human milk: composition and health benefits. La Pediatria Medica e Chirurgica 2017; 39(2):47-52. https://doi.org/10.4081/pmc.2017.155

4. Schanler RJ. Infant benefits of breastfeeding [Internet] [cited 2018 Aug 18] Available from: https:/www.uptodate.com/ contents/infant-benefits-of-breastfeeding? source=search_re sult\&search $=$ infant + benefits + of + breastfeeding\&selectedTit le $=1 \sim 150$.

5. Schanler RJ. Maternal and economic benefits of breastfeeding [Internet] [cited 2018 Aug 18] Available from: https://www. uptodate.com/contents/maternal-and-economic-benefits-ofbreastfeeding? source $=$ search_result\&search $=$ maternal + and + economic+benefits\&selectedTitle $=1 \sim 150$.

6. Kim JH, Unger S. Human milk banking. Paediatr Child Health 2010; 15(9):595-598.

https://doi.org/10.1093/pch/15.9.595

7. Leung JCY, Yau SY. Perceptions of breastfeeding mothers on breast milk donation and establishment of human breast milk bank in Hong Kong: A Qualitative Study. Int J Nurs 2015; 2(2):72-80.

https://doi.org/10.15640/ijn.v2n2a9

8. Jang HL, Cho JY, Kim M, Kim EJ, Park EY, Park SA. et al. The experience of human milk banking for 8 years: Korean perspective. J Korean Med Sci 2016; 31(11):1775-1783. 
https://doi.org/10.3346/jkms.2016.31.11.1775

9. Machado R, Campos-Calderon C, Montoya-Juarez R, Schmidt-RioValle J. Experiences of human milk donation in Andalucia-Spain: a qualitative study. Enfermeria Global 2015; 14(37):114-124.

10. Abhulimhen-Iyoha BI, Okonkwo IR, Ideh RC, Okolo AA. Mothers' perception of the use of banked human milk for feeding of the infants. Niger J Paed 2015; 42(3):223-227.

11. Gürol A, Ozkan H, Celebioğlu A. Turkish women's knowledge and views regarding mother's milk banking. Collegian 2014; 21(3):239-244.

https://doi.org/10.1016/j.colegn.2013.05.002

12. Lysovienė E., Ivanauskienė V., Stonienė D., Skorobogatova N., Vazgienè R., Židonienė K. ir kt. Pirmasis Lietuvoje donorinio motinos pieno bankas. Lietuvos akušerija ir ginekologija, 2017; 10(1):62-68.

13. European Milk Bank Association [Internet] [cited 2018 Aug 18] Available from: http://europeanmilkbanking.com/.

14. Virano A, Coscia A, Tonetto P, Perathoner C, Bertino E, Gardois $P$. et al. Human milk donation in Northern Italy: barriers, facilitators and information sources. World J Res Rev 2017; 4(5):64-70.

15. Pimenteira Thomaz AC, Maia Loureiro LV, da Silva Oliveira T, Furtado Montenegro NC, Dantas Almeida Júnior E, Fernando Rodrigues Soriano C. et al. The Human milk donation experience: motives, influencing factors, and regular donation. J Hum Lact 2008; 24(1):69-76. https://doi.org/10.1177/0890334407310580

16. Ekșioğlu A, Yeşil Y, Turfan EÇ. Mothers' views of milk ban- king: sample of İzmir. Turk Pediatri Ars 2015; 50(2):83-89.

https://doi.org/10.5152/tpa.2015.2406

THE DETERMINANTS OF PARTICIPATION IN MOTHER'S MILK DONATION OF POSTPARTUM WOMEN

A.Vaškelytė, J.Aniulytė

Key words: postpartum women, milk donation, milk bank, participation determinants.

Summary

The aim of this research was to analyse the determinants of participation in mother's milk donation of postpartum women. The study was done in one of the hospitals of Lithuania Department of Obstetrics and Gynaecology and Department of Neonatology. 257 postpartum women participated in the research. An anonymous questionnaire was made by authors for this study.

The results showed that the majority of postpartum women would like to become a milk bank donor and use the milk from milk bank for their newborn. The main reason of willingness to donate own milk for the milk bank was intention to help other mothers and newborns in need and the leading occasion for unwillingness to donate breast milk was fear of not having enough milk for own newborn. The main reason of willingness to use donor milk from milk bank was opinion that mother's milk is the best source of nutrition for newborn and the leading occasion for unwillingness to use donor milk was preferment of other way of nutrition.

Correspondence to: alina.vask@gmail.com

Gauta 2018-09-03 